\title{
Association Between Interleukin 1 Beta $(I L-1 \beta)$ Gene Variation and Temporal Lobe Epilepsy with Hippocampal Sclerosis
}

\author{
Interlökin 1 Beta (IL-1 $\beta$ ) Gen Varyasyonu ile Hippokampal Sklerozlu Temporal Lob
} Epilepsisi İlişkisi

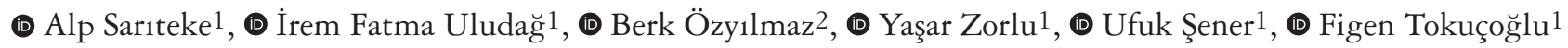 \\ 1 University of Health Sciences Turkey, Izmir Tepecik Training and Research Hospital, Clinic of Neurology, Izmir, Turkey \\ 2University of Health Sciences Turkey, Izmir Tepecik Training and Research Hospital, Clinic of Genetic Diseases, Izmir, Turkey
}

\begin{abstract}
Objective: We aimed to determine the association between a polymorphism in the promoter region of the $I L$-1beta gene resulting in enhanced gene transcription and the clinical phenotype of temporal lobe epilepsy with hippocampal sclerosis (TLE+HS).

Materials and Methods: The frequency of a single nucleotide polymorphism (SNP) that results in a $\mathrm{C}>\mathrm{T}$ transition of 511 base pairs that are five prime to the transcription start site of the IL-1beta gene in a group of 21 patients with TLE+HS, 21 patients with temporal lobe epilepsy without hippocampal sclerosis (TLE-HS), and 23 healthy volunteers.

Results: The frequency of the -511T allele was 11/21 in the TLE-HS group, 13/21 in the TLE+HS group, and 12/23 in the control group. Chi-square analysis of genotype and allele distribution showed no significant difference between the patients in TLE+HS, TLE-HS, and control group.

Conclusion: There was no association between the $-511 / \mathrm{C}>\mathrm{T}$ SNP variation and TLE $+\mathrm{HS}$.

Keywords: IL-1beta, temporal lobe epilepsy, hippocampal sclerosis, epilepsy, genetics

$\ddot{O} \mathbf{z}$

Amaç: IL-1beta geni promotor bölgesinde artmış gen transkripsiyonu ile sonuçlanan bir polimorfizm ve hippokampal sklerozlu temporal lob epilepsisi klinik fenotipi (TLE+HS) arasındaki bir ilişki olup olmadığının araştııılması amaçlanmıştır.

Gereç ve Yöntem: Yirmi bir TLE+HS, 21 hippokampal skleroz olmayan temporal lob epilepsisi (TLE-HS) ve 23 sağlıkl1 gönüllüde $I L-1$ beta geni 511 . baz çiftinde $\mathrm{C}>\mathrm{T}$ geçişine neden olan tek nükleotid polimorfizminin (SNP) sıklı̆̆

Bulgular: -511T alleli sıklı̆̆ı TLE-HS'de 11/21, TLE+HS'de 13/21 ve normal kontrol grubunda 12/23 olarak bulunmuştur. Genotip ve allel dağılımının analizi TLE +HS, TLE-HS ve kontrol grupları arasında -511T alleli sıklığı açısından fark olmadı̆̆ını göstermiştir.

Sonuç: Bu çalışmanın sonuçları -511/C>T SNP varyasyonu ile TLE+HS arasında bir ilişki varlığını göstermemektedir.

Anahtar Kelimeler: IL-1beta, temporal lob epilepsisi, hippokampal skleroz, epilepsi, genetik
\end{abstract}

\section{Introduction}

The etiology of temporal lobe epilepsy with hippocampal sclerosis (TLE+HS) is controversial and likely multifactorial. Acquired lesions, prolonged febrile convulsions (PFC), and genetic predisposition to HS have been implicated as the contributing factors. Histopathological, genetic, and magnetic resonance imaging (MRI) studies have shown inconsistent results regarding the etiology of TLE+HS $(1,2,3)$.

The long arm of chromosome 2 contains three genes of the interleukin (IL)- 1 family: $I L-1 \beta, I L-1 \alpha$, and $I L-1 R A$ (IL- $1 \beta$ receptor antagonist). $I L-1 \beta$ polymorphisms have been associated with

Address for Correspondence/Yazışma Adresi: İrem Fatma Uludağ Assoc. Prof., University of Health Sciences Turkey, Izmir Tepecik Training and Research Hospital, Clinic of Neurology, Izmir, Turkey

Phone: +90 5304690368 E-mail: fatmairem@yahoo.com ORCID: orcid.org/0000-0003-2919-2141

Received/Geliş Tarihi: 07.09.2020 Accepted/Kabul Tarihi: 02.10.2021

${ }^{\circ}$ Copyright 2021 by Turkish Neurological Society

Turkish Journal of Neurology published by Galenos Publishing House. 
epilepsy and other conditions. The most frequent polymorphisms identified in $I L-1 \beta$ are $C$-to- $T$ transitions at positions $-511,-31$, or +3954 from the transcriptional start site. The single nucleotide polymorphism (SNP) at position -511 (rs16944) results in enhanced gene transcription and an increased expression of the encoded protein. The enhancement of the transcription of $I L$ $1 \beta$ depends on the haplotype of the promoter region. The rate of transcription is strongly increased when the IL- $1 \beta-31 \mathrm{C}$ allele is present but significantly lower with the IL-1 $\beta-31 \mathrm{~T}$ allele (4). The overexpression of $I L-1 \beta$ due to IL-1 $\beta-511$ T SNP might contribute to the development of hippocampal neuronal damage and eventually result in TLE+HS. This assumption is supported by experimental and clinical studies, but has not been confirmed in other studies from different populations $(5,6,7,8,9,10)$.

In this study, we aimed to determine the association between the $I L-1 \beta$ gene polymorphism and the clinical phenotype of TLE+HS.

\section{Materials and Methods}

This study included patients admitted to our epilepsy outpatient unit, department of neurology. A total of 21 patients with TLE+HS, 21 patients with temporal lobe epilepsy without hippocampal sclerosis (TLE-HS), and 23 healthy ethnically matched volunteers (control were enrolled for the study). All patients and healthy volunteers (control) visited the hospital between September 2014 and February 2017. All subjects signed the informed consent forms and the study was approved by the Local Ethics Committee of the University of Health Sciences Turkey, Izmir Tepecik Training and Research Hospital (date: 29/12/2014, no: 21). Both patients and the control were of Turkish ancestry. Age, gender, family history, and febrile seizures of the patients and control were recorded. All patients were having focal onset seizures with impaired awareness. The diagnoses of TLE-HS and TLE + HS based on clinical history, electroencephalography (EEG), and MRI were recorded. All EEGs were recorded with a 21-channel Nihon Kohden Neurofax JE-921A EEG machine using the international 10-20 system for electrode placement. Interictal spikes or sharp waves with a maximum over the temporal lobe are shown for each patient.

MRI studies were performed on a 1.5 Tesla system with sagittal and axial T1, axial and coronal T2, and fluid-attenuated inversion recovery sequences. The MRI images were interpreted by an experienced neuroradiologist without knowledge of clinical or EEG findings. MRI findings suggestive of HS were abnormal signal or atrophic change on T2-weighted images in either the hippocampus/amygdala or the temporal lobe. The hippocampal areas on the coronal T2-weighted MR images were measured and if the hippocampal volume in one side is smaller by $20 \%$ or more than that of the other side, hippocampal atrophy is diagnosed (5). Patients with unilateral hippocampal sclerosis were classified in the TLE+HS group, while the patients without epileptogenic foreign-tissue lesions on the MRI findings were classified in the TLE-HS group. Febrile convulsions (FC) lasting more than 15 minutes were termed PFC. Genomic DNA was isolated from the peripheral blood sample. In the promoter region of $I L-1 \beta$, precisely at position -511 , the $\mathrm{C}$ allele is the most common and the $\mathrm{T}$ allele is the putative susceptibility factor that causes an increase in IL-1 $\beta$ levels. We investigated the SNP that results in a $\mathrm{C}>\mathrm{T}$ transition at this position. The target region of the genomic DNA was amplified by polymerase chain reaction. He amplified products were digested by Aval (New England Biolabs) restriction endonuclease. Genotypes were scored by two independent readers.

\section{Statistical Analysis}

Data were analyzed using the IBM SPSS for Windows, Version 20.0 (IBM Corp., Armonk, N.Y., USA). Data were presented as frequencies and means. Chi-square $\left(\chi^{2}\right)$ or Fisher's Exact test was used to compare the groups. The level of significance was $\mathrm{p}<0.05$.

\section{Results}

The demographic and clinical characteristics of the patients are shown in Table 1 . The control group comprised 10 women and 13 men (mean age: $36.1 \pm 7.1$ years; age range: $18-50$ years). The age at onset of epilepsy was earlier for TLE+HS patients than for TLE-HS patients. TLE+HS was more likely to be preceded by PFC than TLE-HS; however, these differences were not statistically significant.

The frequency of the $-511 \mathrm{~T}$ allele was $11 / 21$ in the TLE-HS group, $13 / 21$ in the TLE+HS group, and 12/23 in the control group. The CC genotype was most frequently observed in the control group compared to the TLE+HS and TLE-HS groups. The TC genotype was more frequently observed in the TLE + HS group compared to the TLE-HS and control groups. Statistical analysis of the genotype and allele distribution showed no significant difference between the TLE+HS, TLE-HS, and control group. The genotypes of the patients with and without prolonged febrile seizures were similar (Table 2).

\section{Discussion}

In the present study, there was no association of the variation at position -511 of the promoter region of $I L-1 \beta$ in the TLE + HS patients compared to either the TLE-HS patients or healthy volunteers.

Kanemoto et al. (5) reported an overrepresentation of the allele $-511 \mathrm{~T}$ in Japanese TLE + HS patients compared to controls. They suggested that, in the homozygotes for $I L-1 \beta-511$, minor events in development, such as FC, could trigger a cascade that leads to TLE + HS. However, these findings have not been replicated by other studies with Asian, European, and Turkish populations

\begin{tabular}{|c|c|c|}
\hline & $\mathrm{TLE}+\mathrm{HS}$ & TLE-HS \\
\hline $\mathrm{n}$ & 21 & 21 \\
\hline Female/male & $10 / 11$ & $12 / 9$ \\
\hline Age & $35.9 \pm 10.9(19-50)$ & $37.4 \pm 13.7$ \\
\hline Age at epilepsy onset & $9.5 \pm 8.8(1-28)$ & $16.4 \pm 11.3$ \\
\hline PFC & 9 & 6 \\
\hline Number of seizures/year & $20.4 \pm 29.1(1-120)$ & $36.7 \pm 33.6$ \\
\hline Family history of epilepsy & 8 & 6 \\
\hline \multicolumn{3}{|c|}{$\begin{array}{l}\text { TLE+HS: Temporal lobe epilepsy with hippocampal sclerosis, TLE-HS } \\
\text { Temporal lobe epilepsy without hippocampal sclerosis, PFC: Prolonged febril } \\
\text { convulsions, ages in years, values in mean } \pm \text { standard deviation }\end{array}$} \\
\hline
\end{tabular}




\begin{tabular}{|c|c|c|c|c|c|c|c|}
\hline & \multicolumn{2}{|c|}{$\mathrm{CC}$} & \multicolumn{2}{|c|}{ TC } & \multicolumn{2}{|c|}{ TT } & \multirow{2}{*}{$\mathrm{p}$} \\
\hline & $\mathrm{n}$ & $\%$ & $\mathrm{n}$ & $\%$ & $\mathrm{n}$ & $\%$ & \\
\hline TLE+HS & 8 & 38.1 & 10 & 47.6 & 3 & 14.3 & \multirow{3}{*}{0.53} \\
\hline TLE-HS & 10 & 47.6 & 5 & 23.8 & 6 & 28.6 & \\
\hline Controls & 11 & 47.8 & 6 & 26.1 & 6 & 26.1 & \\
\hline PFC (+) TLE & 8 & 53.3 & 4 & 26.7 & 3 & 20 & \multirow{2}{*}{0.56} \\
\hline PFC (-) TLE & 10 & 37 & 11 & 40.7 & 6 & 22.2 & \\
\hline \multicolumn{8}{|c|}{$\begin{array}{l}\text { TLE+HS: Temporal lobe epilepsy with hippocampal sclerosis, TLE-HS } \\
\text { Temporal lobe epilepsy without hippocampal sclerosis, PFC: Prolonged febrile } \\
\text { convulsions }\end{array}$} \\
\hline
\end{tabular}

$(6,7,8,9,11,12)$. Buono et al. (6) suggested that $I L-1 \beta$ promoter region polymorphism does not act as a strong susceptibility factor for TLE $+\mathrm{HS}$ in individuals of European ancestry. Results of the studies on German populations were also concordant with this observation $(11,12)$. In the Chinese population, Jin et al. ((7) did not find an association between $I L-1 \beta-511$ polymorphism and the development of HS. No correlation was found between IIL$1 \beta$ polymorphisms and TLE + HS in Turkish patients (8). Despite that these studies showed a lack of association between $I L-1 \beta$ polymorphism and TLE $+\mathrm{HS}$, a meta-analysis by Kauffman et al. (13) in 2008 demonstrated a modest association between TLE+HS and $I L-1 \beta-511 \mathrm{~T}$ polymorphism.

Kanemoto et al. (10) also showed a higher frequency of -511 allele in patients with PFC compared to patients with simple FC. Other studies including patients with FC could not demonstrate this association $(8,11,14)$. Our comparison of patients with and without PFC was also concordant with the findings of the aforementioned studies.

The most important factor contributing to the discrepancy between these studies may be the difference in the frequency of this polymorphism among ethnic groups. The occurrence of the $-511 \mathrm{~T}$ allele in the control group is found to be different in Japanese, Chinese, European, and African ancestries $(50 \%, 46 \%, 34 \%$, and $60 \%$ respectively) $(5,6,7)$. Another factor may be the weak or infrequent effect of the susceptibility gene to the etiology of such a complex and multifactorial disease. Jin et al. (7) considered that TLE + HS may be classified phenotypically into early and late onset subtypes, which may be different in genetic basis. In consonant with our study, in studies including a small number of patients, the statistical power to detect minor or moderate susceptibility factors is limited. The diagnosis of TLE+HS was based on MRI findings in our study and in most previous studies $(5,7)$. Although MRI shows minimal false-positive results in the diagnosis of hippocampal sclerosis, usage of its data is more accurate than histopathological data.

\section{Study Limitations}

The limitations of the present study are the small number of subjects and the lack of histopathological data. We also noticed that the association we focused on has been previously studied in the Turkish population.

\section{Conclusion}

$I L-1 \beta-511 \mathrm{~T}$ SNP has been associated with susceptibility to TLE and HS. However, these findings have not been confirmed by other studies. In addition, the role of this genetic variant in the development of these conditions is still controversial. Our data suggest that the $-511 / \mathrm{C}>\mathrm{T}$ SNP in $I L-1 \beta$ is not a strong predisposing factor for TLE + HS in the Turkish population.

\section{Ethics}

Ethics Committee Approval: The study was approved by the Local Ethics Committee of the University of Health Sciences Turkey, Izmir Tepecik Training and Research Hospital (date: 29/12/2014, no: 21).

Informed Consent: All subjects signed the informed consent forms.

Peer-review: Externally and internally peer-reviewed.

\section{Authorship Contributions}

Surgical and Medical Practices: A.S., B.Ö., Concept: A.S., İ.F.U., Design: A.S., İ.F.U., Data Collection or Processing: A.S., B.Ö., Analysis or Interpretation: A.S., İ.F.U., B.Ö., Y.Z., U.Ş., F.T., Literature Search: A.S., Writing: A.S., İ.F.U.

Conflict of Interest: No conflict of interest was declared by the authors.

Financial Disclosure: The authors declared that this study received no financial support.

\section{References}

1. Fernández G, Effenberger O, Vinz B, et al. Hippocampal malformation as a cause of familial febrile convulsions and subsequent hippocampal sclerosis. Neurology 1998;50:909-917.

2. Briellmann RS, Kalnins RM, Berkovic SF, Jackson GD. Hippocampal pathology in refractory temporal lobe epilepsy: T2-weighted signal change reflects dentate gliosis. Neurology 2002;58:265-271.

3. Jackson GD, McIntosh AM, Briellmann RS, Berkovic SF. Hippocampal sclerosis studied in identical twins. Neurology 1998;51:78-84.

4. Chen H, Wilkins LM, Aziz N, et al. Single nucleotide polymorphisms in the human interleukin-1B gene affect transcription according to haplotype context. Hum Mol Genet 2006;15:519-29.

5. Kanemoto K, Kawasaki J, Miyamoto T, Obayashi H, Nishimura M. Interleukin (IL)1beta, IL-1alpha, and IL-1 receptor antagonist gene polymorphisms in patients with temporal lobe epilepsy. Ann Neurol 2000; $47: 571-574$.

6. Buono RJ, Ferraro TN, O'Connor MJ, et al. Lack of association between an interleukin 1 beta (IL-1beta) gene variation and refractory temporal lobe epilepsy. Epilepsia 2001;42:782-784.

7. Jin L, Jia Y, Zhang B, et al. Association analysis of a polymorphism of interleukin 1 beta (IL-1 beta) gene with temporal lobe epilepsy in a Chinese population. Epilepsia 2003;44:1306-1309.

8. Ozkara C, Uzan M, Tanriverdi T, et al. Lack of association between IL-1beta/ alpha gene polymorphisms and temporal lobe epilepsy with hippocampal sclerosis. Seizure 2006;15:288-291.

9. Cavalleri GL, Lynch JM, Depondt C, et al. Failure to replicate previously reported genetic associations with sporadic temporal lobe epilepsy: where to from here? Brain 2005;128(Pt 8):1832-1840.

10. Kanemoto K, Kawasaki J, Yuasa S, et al. Increased frequency of interleukin1beta-511T allele in patients with temporal lobe epilepsy, hippocampal sclerosis, and prolonged febrile convulsion. Epilepsia 2003;44:796-799. 
11. Tilgen $\mathrm{N}$, Pfeiffer $\mathrm{H}$, Cobilanschi J, et al. Association analysis between the human interleukin 1beta (-511) gene polymorphism and susceptibility to febrile convulsions. Neurosci Lett 2002;334:68-70.

12. Heils A, Haug K, Kunz WS, et al. Interleukin-1 beta gene polymorphism and susceptibility to temporal lobe epilepsy with hippocampal sclerosis. Ann Neurol 2000;48:948-950.
13. Kauffman MA, Moron DG, Consalvo D, Bello R, Kochen S. Association study between interleukin 1 beta gene and epileptic disorders: a HuGe review and meta-analysis. Genet Med 2008;10:83-88.

14. Kira R, Torisu H, Takemoto M, et al. Genetic susceptibility to simple febrile seizures: interleukin-1 beta promoter polymorphisms are associated with sporadic cases. Neurosci Lett 2005;384:239-244. 